\author{
M. F. Popa
}

\title{
Postmortem Traumatic Lesions Produced In Storm Conditions In Black Sea - Gase Presentations
}

"Ovidius" University Constanța, Faculty of Medicine, Forensic Medicine Department

\begin{abstract}
Drowning represents a mechanical asphyxia form, produced by the obstruction of the air pathways, obstruction in which the air is replaced by a fluid. For the drowning to take place is enough that the breathing orifices (mouth, nose) to be placed in the fluid environment.

This paper aims to analyze some special drowning cases, cases in which the traumatic lesions encountered are very rare in the forensic pathology.

These postmortem traumatic lesions are very rare encountered in cases of drowning. In the international special literature there are no such cases presented, because these types of traumatic injuries are usually present in death situations due to a much more violent death mechanism - blunt object trauma, driving or train accidents.

In the international special literature this types of lesions are not encountered, this aspect being very important to be known and noted, for a pertinent differential diagnosis with other more violent types of death.
\end{abstract}

Key words: alcoholic hepatitis, bacteremia, pulmonary infections, urinary tract infections

\section{Introduction}

Drowning represents a mechanical asphyxia form, produced by the obstruction of the air pathways, obstruction in which the air is replaced by a fluid. For the drowning to take place is enough that the breathing orifices (mouth, nose) to be placed in the fluid environment [1]. Drowning is a part of the submersions chapter, from which submersion in powder, grains also take part, the most frequent being submersion in water [2]. Drowning can take place in fresh and salt water, the macro and microscopic lesions being distinct, this fact making a differential diagnosis possible. Morphopathologically speaking we can encounter lesions due to water, but also lesions due to animals, specific drowning modifications, lesions produced by passive hitting blunt objects in the water and putrefaction [1]. Lab tests can be made, blood, plankton, diatoms also being among the tests conducted in drowning cases.

\section{Material and Method}

This paper aims to analyze some special drowning cases, cases in which the traumatic lesions encountered are very rare in the forensic pathology. The selected cases are from the County Forensic Medicine Constanța archive, from the year 2012. As a particularity of these cases, drowning of the victims and the time passed until they were recovered happened in severe meteorological conditions. 
The aim of these paper is to identify and analyze lesions encountered in this drowning cases, to realize a differential diagnosis with similar lesions produced by other tanatogenerator mechanisms and to add new types of traumatic marks besides those considered to be "classic" for drowning.

\section{Case Presentations}

\section{Case 1}

Forensic report no. 4XX/A3/2012

\section{Objectives:} causes of it

- The approximate time of death, nature and

- The presence of violent trauma, and if so, what's the nature of it, the producing mechanism and the causality relation with death

\section{- Alcohol level in the blood}

History: In the morning of 23.07.2012, around 06 a.m., B.-M. C. entered in the waters of Black Sea and was never seen coming out. In the morning of 24.07.2012, Costinesti police department was announced by the lifeguards of the Obelisc area that from the water was retrieved the dead body of young man - B.-M. C.

\section{Necropsy report:}

External exam - male body, 15 years old, 165 $\mathrm{cm}$ height, normostenic

Trauma marks:

- Left parietal zone - three blunt plagues cu unregulated edges thru which the bone level is visible with tissue bridges in extremities, without blood infiltrate

- $\quad$ Right half upper (cranial) face, blunt plague with soft tissue avulsion, eye globe missing, rupture of the zigomatic bone articulation, cominutives fractures of the orbital wall, right maxillary anterior

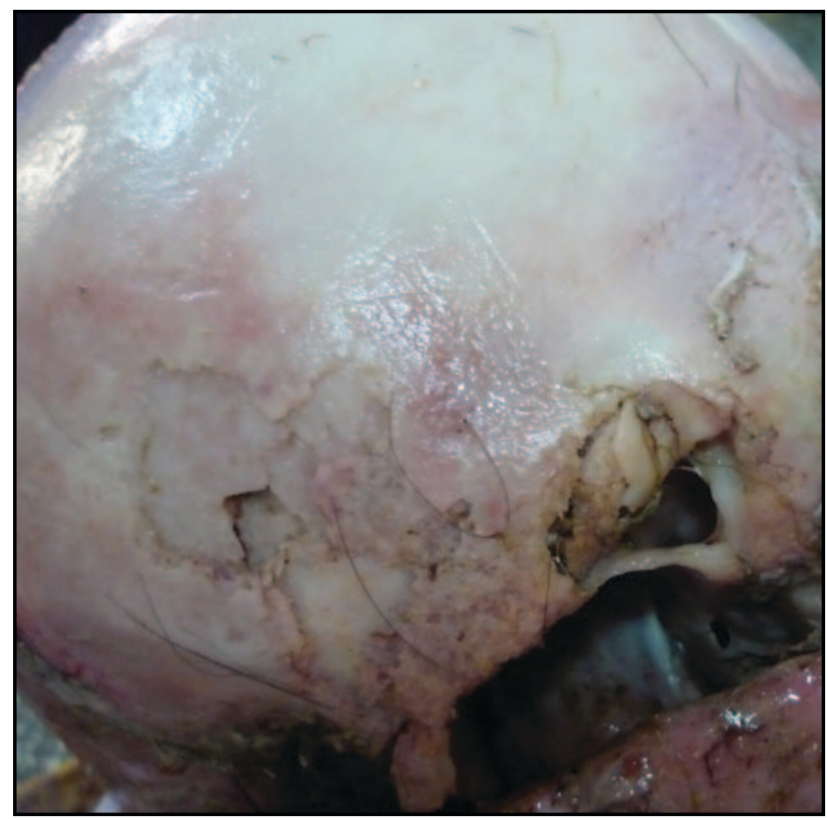

Figure 1 - Right frontal area, above the eye cavity, the external bone structure is missing on a 1,5 cm area, unregulated edges

wall fracture (sinus), nasal cartilages destruction; none of the lesions exercising blood infiltrate

- Multiple continuity solutions on the body and limbs, vary in shape and size with soft tissue destruction reaching the left clavicle and $1 / 3$ distal

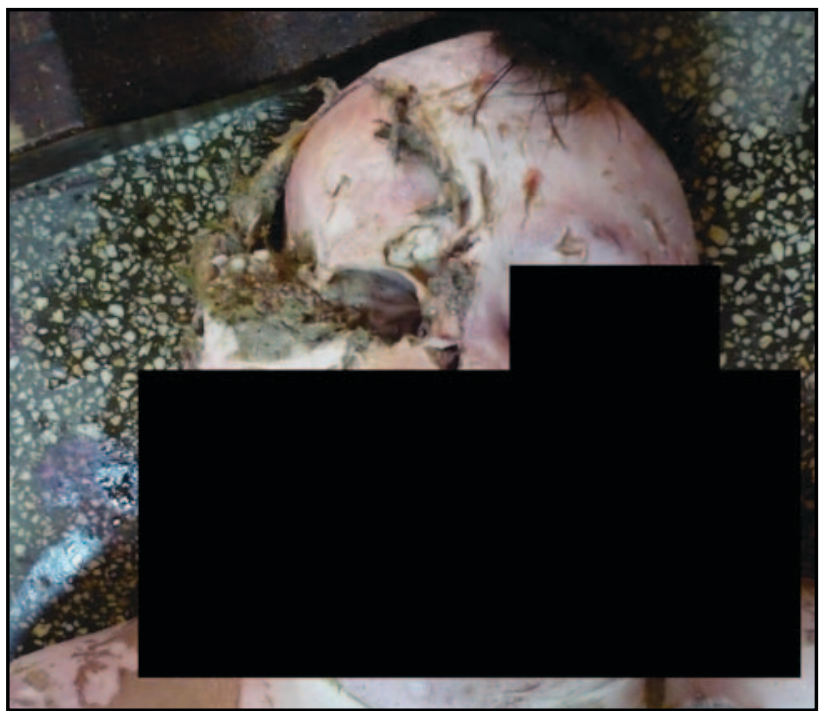

Figure 2 - Right half upper (cranial) face, blunt plague with soft tissue avulsion, eye globe missing, rupture of the zigomatic bone articulation, cominutives fractures of the orbital wall, right maxillary anterior wall fracture (sinus), nasal cartilages destruction 
on the anterior-internal site of left lower leg region, reaching the bone level; none of the lesions exercising blood infiltrate

- Right frontal area, above the eye cavity, the external bone structure is missing on a $1,5 \mathrm{~cm}$ area, unregulated edges and correspondent to that an elliptical internal bone structure missing $1,5 \mathrm{~cm}$ in diameter.

- Left mandibulary arch fractured

These postmortem traumatic lesions are very rare encountered in cases of drowning. In the international special literature there are no such cases presented, because these types of traumatic injuries are usually present in death situations due to a much more violent death mechanism - blunt object trauma, driving or train accidents.

\section{Case 2}

Forensic report no. 5XX/A3/2012

\section{Objectives:} causes of it

The approximate time of death, nature and

- The presence of violent trauma, and if so, what's the nature of it, the producing mechanism and the causality relation with death

History: Unidentified body was found on the beach near Agigea city.

\section{External Examination:}

- Unidentified dead body, $183 \mathrm{~cm}$ in height

- It present soft tissues remains on the limbs and on the pelvic area

- Major loss of soft tissues - epicranium, duramater, brain, neck area, pharynx, larynx, esophagus, lungs, heart, mediastinum, digestive tract, spleen, renal system,

- Loss of soft tissue on the thoracic wall

Traumatic lesions of this magnitude have never been encountered so far on this type of death, more often being associated with extreme violent scenarios - explosions, plane crushes, etc.

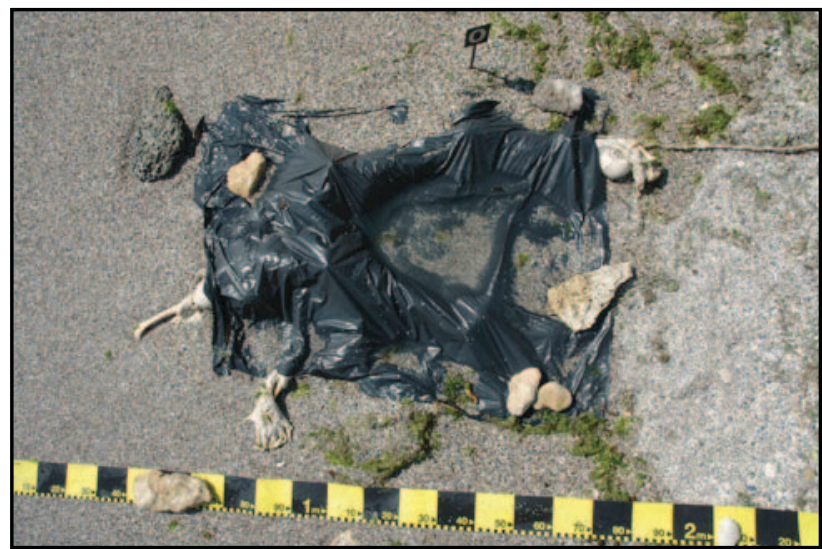

Figure 3 - Unidentified dead body found on the beach near Agigea city

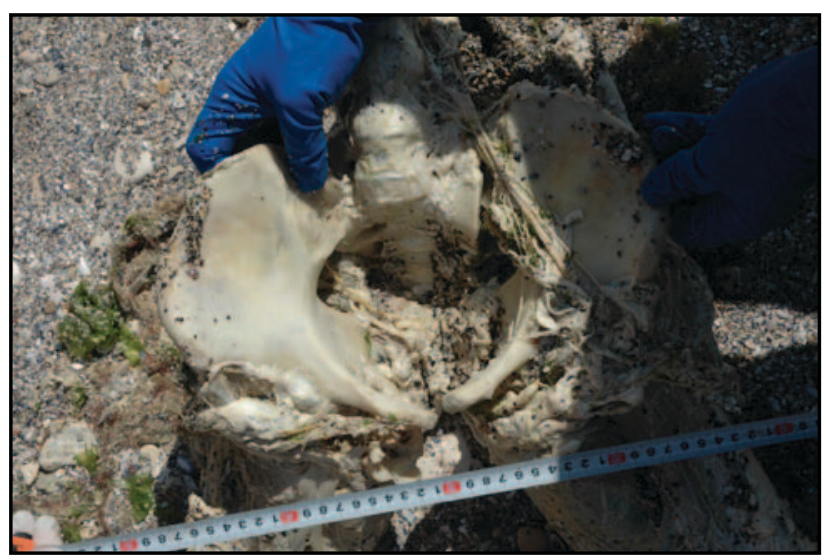

Figure 4 - Major loss of soft tissue and organ systems

\section{Conclusions}

- Traumatic lesions encountered in this cases are very special, not usually being encountered in drowning cases and not considered being "classic"

- In the international special literature this types of lesions are not encountered, this aspect being very important to be known and noted, for a pertinent differential diagnosis with other more violent types of death

- These kind of trauma marks, by their nature and complexity, can conduct to error the forensic pathologist and also the judiciary organs, leading them on false tracks (ex. investigating a possible 
crime).

- These cases proves the complexity of the traumatic lesions that we can encounter in cases of drowning in extreme weather conditions (storms).

\section{References}

1. 1. MARIUS POPA - Medicină Legală-Note de curs, Ed. Fundației “Andrei Şaguna”, Constanța -2007, pg.156-160.
2. 2. DAN DERMENGIU, GEORGE CRISTIAN CURCĂ, VALENTIN GHEORGHIU ET ALL - Curs de Medicină Legală, Ed. Tehnoplast Company S.R.L., Bucureşti 2005, pg. 130

3. 3. BELIŞ V., Tratat de Medicină Legală, Volumul I-II, Editura Medicală, București, 1995.

4. 4. CIUREA AV, DAVIDESCU HB: Traumatologie craniocerebrală. Ed. Universitară "Carol Davila" București, 2006

5. 5. PANAITESCU V. - Metode de investigatie în practica medico-legală, Editura Litera, Bucureşti, 1984

6. 6. SCRIPCARU GH. - Medicină legală, Editura Didactică şi Pedagogică R.A., Bucureşti, 1993 